\title{
Biology of surgeonfish Acanthurus nigrofuscus with emphasis on changeover in diet and annual gonadal cycles
}

\author{
Lev Fishelson ${ }^{1}$, Linn W. Montgomery ${ }^{2}$, Arthur H. Myrberg, Jr. ${ }^{3}$ \\ ${ }^{1}$ Department of Zoology, Tel Aviv University, Ramat Aviv 69978, Israel \\ ${ }^{2}$ Department of Biological Sciences, Northern Arizona University, Flagstaff, Arizona 86011, USA \\ ${ }^{3}$ Rosenstiel School of Marine and Atmospheric Sciences, University of Miami, Miami, Florida 33149, USA
}

\begin{abstract}
A 3 yr study was conducted on the feeding biology and reproductive strategies of Acanthurus nigrofuscus (Acanthuridae, Teleostei) found along the coral reefs of the Gulf of Aqaba and forming there the major biomass of algivorous fish. The diet of this surgeonfish is based on algae selected from turf communities growing on subtidal rocky surfaces. At some sites A. nigrofuscus form schools that migrate daily from nocturnal refuges in coral reefs to foraging sites on the intertidal, covering distances of 500 to $600 \mathrm{~m}$. During summer the main food items are brown and red algae; in winter, lush green algae. This changeover appears to provide the food-base for accumulation of fat and recrudescence of gonadal activity initiating in March-April. Reproduction occurs in large schools of 2000 to 2500 fish and on selected sites, continuing from May to September. Spawning occurs daily from 1800 to $1830 \mathrm{~h}$, after which the fish depart for their night refuges. Peak of gonadal activity is in July-August, after which an increase of pre- and postovulatory atretic bodies is prominent. In female post-spawned gonads, cysts of spermatogonia appear and remain until renewed normal activity in February-March. Histological evidence and possible explanation of this phenomenon are provided.
\end{abstract}

\section{INTRODUCTION}

The surgeonfishes, family Acanthuridae, form a dominant element of the algivorous fish biomass of coral reefs all over the world. The life history and behavior of various species have been studied in nature by Randall (1961a, b); Jones (1968), Barlow (1974), Robertson et al. (1979), and Robertson (1983). Most recently, the present authors conducted a 3 yr study on acanthurid fishes in the vicinity of Eilat, Gulf of Aqaba, Red Sea, particularly focussing on Acanthurus nigrofuscus, the most common surgeonfish species in this area. Various results of this study are published (Fishelson et al. 1985a, b, Myrberg et al. 1985).

The segment of our study summarized in this paper deals with the results of an investigation that started in April 1981 and continued on a monthly sampling basis until May 1984. Its main objectives were to follow specific activity patterns of Acanthurus nigrofuscus throughout the year, as well as gonadal development, in connection with reproductive cycles. As previously shown by Myrberg et al. (1985), these fish occur in groups of a few to a few hundred individuals, that aggregate daily in large schools during the spawning season (May to September) to perform a highly ritualized and synchronized liberation of gametes. Therefore, it was of interest to study the effect of these prolonged spawning activities on the general patterns of behavior of these fish, as well as the gametogenic activities in the gonads of the adults.

\section{STUDY SITES}

This study focussed on 2 sites near Eilat, Israel, that will be described in detail elsewhere (Myrberg et al. unpubl.).

Study Site 1: Larome Beach. This site begins offshore of the Aquasport Centre and Larome Hotel, extending along some $180 \mathrm{~m}$ of the shoreline (Fig. 1). Here the intertidal and the shallow subtidal are formed by a flat, beachrock formation. An almost uninterrupted carpet of turf-algae cover extends along the gentle slope just seawards of the shore. Landwards along this carpet, dense populations of limpets Cellana rothi, periwinkles Planaxis sulcata and Nodilittorina tuberculata, as well 


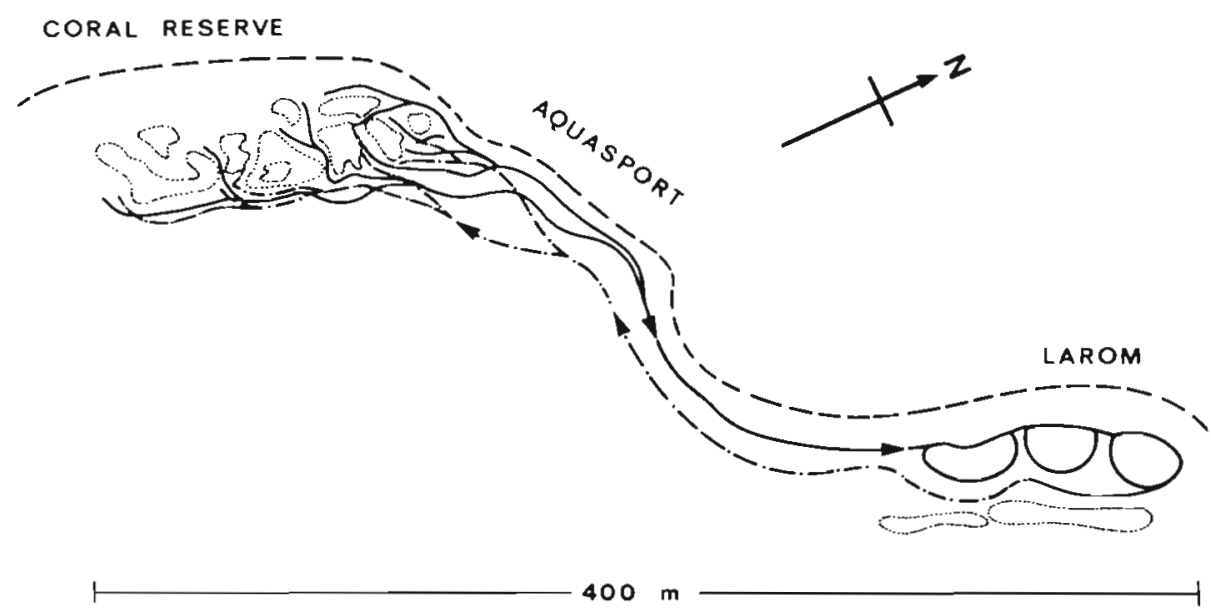

Fig. 1. Study site at Larome Beach, Eilat, Israel. Arrows show the directions to and from the foraging site

as blennies Istiblennius rivulatus, I. edentulus and Salarias fasciatus, graze on this belt of algae. Seawards the same belt serves as feeding grounds for large populations of sea urchins Diadema setosum and Tripneustes gratilla. Between these 2 lines of grazers, the width of the algae belt is 6 to $10 \mathrm{~m}$. The main algae that occur here are tiny dichotomic and filiform, forming a complicated meshwork that shelters many invertebrates and acts as a trap for sediment. The most common of these algae are: Gelidium spp.; Cladophora spp.; Centrocerus clavulatum; Hypnea spp.; Polysyphonia spp.; Cystoseira spp.; Valonia aegagrophila; Ceramium strictum; Jania adherens; Chondria spp.; Padina pavona; Lyngbia spp.; Enteromorpha spp. Adjacent to this site are the coral reefs of the Eilat Coral Reserve, partly marked in Fig. 1.

Study Site 2: Lighthouse. Situated south of the first site and south of the Marine Biology Laboratory, Eilat, close to a shore-situated lighthouse and $1.8 \mathrm{~km}$ from the Larome site, this study area is characterized by a boulder-rocky substrate that extends from the supratidal beachrock down to a depth of 2 to $2.5 \mathrm{~m}$. The bottom is covered by boulders, rocks and small stones and pebbles, interspersed with soft sediment. Seawards, shallow water coral patches and knolls are situated, with many hiding places and caverns in them. The shallow boulder-pebble zone is covered by a turfalgae assemblage, resembling that at the Larome site. A different algae cover occurs on deeper parts, especially on dead corals, here dominated by macrophytic Laurencia spp., Lobophora variegata, Caulerpa serrulata and Ulva lactuca. These macrophytes grow also among and between the coral colonies.

\section{METHODS}

After an initial survey, specific study sites were established. Tagging of fish began in April and con- tinued until December 1982. In total, some 600 individuals were marked with tags distinctive in colour and point of attachment on the fish for each study site. During the study, records of tagged fish over a period of more than 2 yr showed that members of the species are stationary and spend their adult lives in well-defined habitats. Recapture of tagged fish provided data on growth

Direct observations were performed on a monthly basis, 5 to $7 \mathrm{~d}$ each month, by snorkeling and SCUBA. These observations usually commenced shortly after or before sunrise and ended before or after sunset. Using a clip-board with waterproof paper and a watch, records were made of the various activities performed by the fish and the sites where the fish spent their time feeding. From these data a time-budget for feeding could be established.

Samples of 6 to 15 fish were collected each month for gonad analysis. All fish were measured (standard length; SL), weighed, and dissected shortly after capture. For calculation of gonadal index, the fresh gonads were separated and weighed to an accuracy of $10 \mathrm{mg}$. The gonads were fixed in Bouins or in a Carnoy mixture of formol and ethanol. From some 160 gonads, serial sections were prepared, stained in Iron and Delafield's Hematoxylin-Eosin or Mallory trichrom. These monthly gonadal sections were analysed using a Visopan screen microscope and a Zeis ultrascope. The Visopan enabled a quantitative analysis of ovocyte numbers and dimensions along transects of gonadal sections.

\section{RESULTS}

\section{Daily movements}

As mentioned by Myrberg et al. (1985), Acanthurus nigrofuscus occurs consistently along the shores of Eilat, in groups of various sizes. During the day, these 
fish feed communally on the turf-algae of the lower intertidal and shallow subtidal zones. At the Larome site, groups usually consist of 250 to $400 \mathrm{fish}$, and their home range extends over some $800 \mathrm{~m}$ of coastline, divided into 2 well separated areas: the night-refuge site within the framework of the corals in the Eilat Coral Reserve, and the daily foraging site over the Larome subtidal beachrock platform (Fig. 1). These 2 sites are separated by a stretch of $150 \mathrm{~m}$ of barren sandy bottom, traversed by the fish coming from or going to the night-refuges.

Daily activity of the fish begins shortly after sunrise. The fish emerge from their night quarters within the coral caverns, immediately forming groups of a few to a few tens of individuals. These, swimming along coral passages, head northwards, joined on their way by additional individuals of the same species. Over the barren and open space, the large groups form single or double lines advancing close to the bottom. As soon as the first fish arrive at the foraging site of the Larome beach rock, usually at 0600 to $0630 \mathrm{~h}$, feeding commences. This causes an initial milling of newcomers. Within 45 min all the fish within a large aggregation are foraging simultaneously and in a dense pack. Detailed analysis of this behaviour will be published separately by Montgomery et al. (unpubl.).

Following such groups for $1 \mathrm{~h}$ it became evident that the Larome groups move over a more or less routine pathway along some $120 \mathrm{~m}$ of shoreline. This revealed a pattern of daily activity. Fig. 2 shows that at 0800 , 1000 and $1200 \mathrm{~h}$ (Lines A, B, C) a selected group continued to feed, moving back and forth along the algae cover. However, in the afternoon (Lines D, E), the group frequently stopped feeding and ascended in the water column, pausing there for some minutes. A part of this group then began slowly to move from the foraging site. Such fish formed small groups and swam south in the direction of the Eilat Coral Reserve and their night-refuges. Within $30 \mathrm{~min}$, all fish had gone from the foraging site. Reaching the corals, the groups split into even smaller groups, and the number of fish decreased as more and more of them entered their retreats. The last individuals disappeared after sunset, but before total darkness descended. This mode of migratory behavior is very persistent. Thus, twice daily, schools of fish move in opposite directions: with the sunrise from their refuges towards the foraging site, and in the late afternoon from the foraging site back to their refuges (Fig. 1). During the summer, this daily activity commences at 0600 to $0630 \mathrm{~h}$ and ends at 1700 to $1730 \mathrm{~h}$. In winter, when the days are shorter, the fish commence foraging at 0700 to $0715 \mathrm{~h}$ and depart for their night quarters at 1615 to $1630 \mathrm{~h}$. In the summer, when afternoon spawning activities dominate the behavior of the fish before sunset (Myrberg et al. 1985) the fish first aggregate for spawning and only later move to their night refuges. This daily migratory pattern is typical of the Larome fish population.

At the Lighthouse site, the behavior of Acanthurus nigrofuscus is different from that of the fish within the Coral Reserve. Here, A. nigrofuscus forms local scattered populations of 10 to 20 individuals each, that remain within a limited home range, where food as well as shelter are provided. The spatial movements of such small groups of fish are limited. For almost $2 \frac{1 / 2}{y r}$ individually marked fish were repeatedly encountered not more than a few meters from the sites where they had been originally marked. During the night, these fish find cover beneath boulders and rocks, or within the nearby coral spurs. These small groups merge to form huge concentrations only for communal spawning on a chosen spot, as does the Larome population (see Myrberg et al. 1985).

\section{Food}

Although a paper dealing with feeding and nutrition in Acanthurus nigrofuscus is in preparation (Montgom-
Fig. 2. Acanthurus nigrofuscus. Daily foraging activity of the school of fish along the Larome Beach. HTM: high tide mark; LTM: low tide mark; A: observed at $0800 \mathrm{~h}$; B: at $1000 \mathrm{~h}, \mathrm{C}$ : at $1200 \mathrm{~h}, \mathrm{D}$ : at 1600 h. Algal cover delineated by striped band
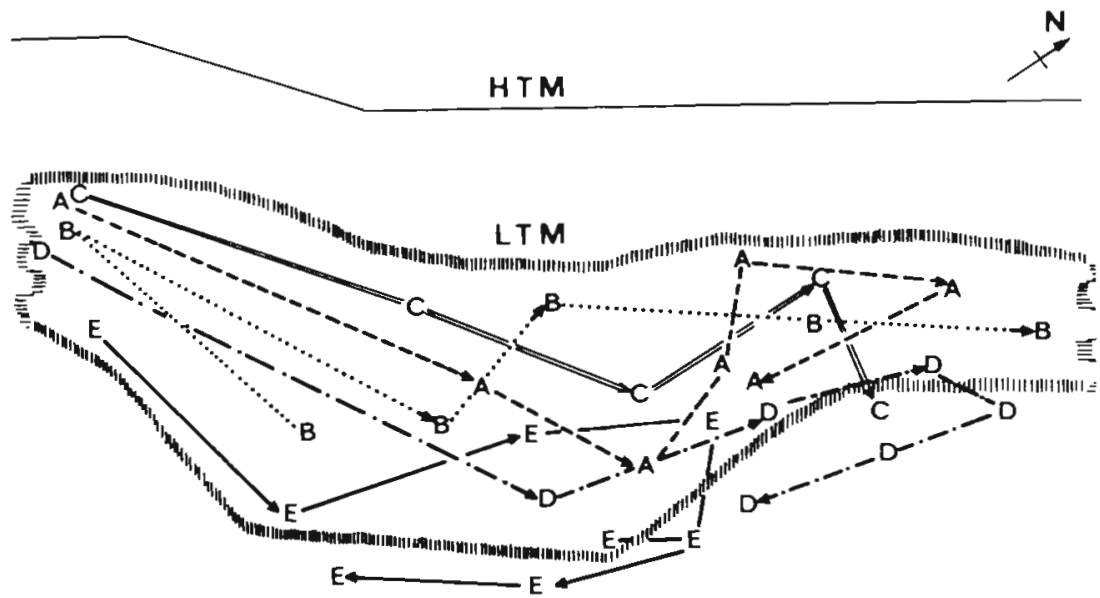
Table 1. Acanthurus nigrofuscus. Gonadal index (gonads as \% of body weight) in specimens of 100 to $140 \mathrm{~mm} \mathrm{SL}$

\begin{tabular}{|c|c|c|c|}
\hline Month & Testes & Ovary & $\begin{array}{l}\text { Condition } \\
\text { factor, } \mathrm{K}\end{array}$ \\
\hline Jun 1982 & 3.5 & 4.1 & 4.7 \\
\hline Jul & 8.2 & 5.2 & 4.4 \\
\hline Aug & 3.7 & 2.6 & 4.7 \\
\hline Sep & 0.8 & 0.6 & 4.4 \\
\hline Oct & 0.3 & 0.9 & 4.1 \\
\hline Nov & 0.2 & 0.3 & 4.6 \\
\hline Dec & 0.2 & 0.4 & 4.4 \\
\hline Jan 1983 & 0.2 & 0.8 & 4.6 \\
\hline Feb & 0.3 & 1.0 & $4.7 \mathrm{GR}, \mathrm{F}$ \\
\hline Mar & 0.2 & 1.1 & 5.4 GR, F \\
\hline Apr & 1.0 & 1.5 & $5.6 \mathrm{GR}, \mathrm{F}$ \\
\hline May & 3.1 & 2.1 & $4.6 \mathrm{~F}, \mathrm{M}$ \\
\hline Jun & 5.4 & 4.4 & $4.9 F, M$ \\
\hline Jul & 6.6 & 6.0 & $4.6 \mathrm{~F}, \mathrm{M}$ \\
\hline \multicolumn{4}{|c|}{$\begin{array}{l}\text { GR: green algae dominated; } F \text { : ovary growth, fat declines; } \\
\text { M: testis growth, fat declines }\left(K=\frac{W \times 100}{L^{3}}\right) \text { where } W= \\
\quad \text { body weight; } L=\text { body length }\end{array}$} \\
\hline
\end{tabular}

ery et al. unpubl.), some data on diet, essential for understanding reproduction, are provided here.

On both the Lighthouse and the Larome sites, the food of Acanthurus nigrofuscus consists of a selection of algae from the turf cover on the rocky substrata. During the summer, these include the tiny growths of Polysyphonia spp., Ceramium strictum, Centroceros clavulatum, Gelidium spp., Lyngbia spp. and a few others.

By late November, green algae of the genera Enteromorpha, Cladophora and Ulva start to flourish, and growing high they cover the turf-forming species. From then on until April, the larger and more easily collected algae form the main biomass of food for these fish. This changeover in diet coincides with the recrudescence of the gonads and preparation for reproduction. As shown by Montgomery et al. (unpubl.), the condition factor $(\mathrm{K})$ of growth (Table 1) is positively correlated with this changeover in the diet of Acanthurus nigrofuscus. Apparently these physiological developments are reinforced by feeding on the more fleshy green algae that are more digestible and easier to forage, and therefore provide more energy for storage and development of gonads. As shown by us, this is also the time when omental fat is formed and when the gonadal fat body, recently discovered in this surgeonfish (Fishelson et al. 1985a), enlarges strongly.

\section{Reproduction}

Data for this section were obtained from some 280 individuals of Acanthurus nigrofuscus dissected during the 2 yr study. Two topics are summarized here: (1) the development of gonads leading to reproduction; (2) post-spawning processes in the germinative tissue.

\section{Development of gonads}

Generally, the gonadal structure of Acanthurus nigrofuscus is similar to that of other percoid teleosts, consisting in both males and females of a bilobe organ with a common, short duct leading towards an opening on a small, urogenital papilla. The lobes of the ovaries are bottle-shaped, and narrower at the base than those of the testis, which are strongly dorso-ventrally flattened. Observations reveal that the gonads are polycyclic and that ripe females ovulate daily during the reproduction season.

The development of egg cells follows a pattern typical of polycyclic teleost ovaries. The primary oocytes occur in a single row, dispersed within the germinal tissue lining the ovary lumen. As prereproductive ripening begins (April), the growth of egg cells causes extension of the ovary lamellae and their protrusion into the ovary lumen (Fig. 3a). Around the growing oocytes an epithelial follicle develops, forming the granulosa and pellucida layers (Abraham et al. 1966, Fishelson 1975a, 1978). This is the beginning of yolk deposition within the cells, and as shown by Yaron (1971), Nagahama \& Kagawa (1982) and others, the granulosa cells are involved in this process. Parallel to this, along the peripheral plasma of the egg cells separates a cortical, dense layer, named zona striata (Götting 1964) or recognized as zona radiata (Stehr \& Hawks 1979) (Fig. 3a, b). This zone is the Anlage of the egg-envelope or chorion. The germinal vesicle also undergoes a ripening process, during which it enlarges and the chromatine bodies multiply and migrate from the vesicle center towards the vesicular membrane. Concomitantly, new primary ovocytes grow in, which will then form the subsequent spawn. As the ripe egg cells attain 250 to $300 \mu \mathrm{m}$ in diameter, the follicular layer becomes stretched and narrow (Fig. 3b). This is the preovulatory stage. As in other fish (Fishelson 1975a), these eggs absorb water, their yolk becomes homogenized and their diameter increases instantly to 400 to $450 \mu \mathrm{m}$ (Fig. 3c, d). This instantaneous growth ruptures the follicle and the eggs are liberated into the ovary lumen. All eggs within the lumen will form the spawn of $1 \mathrm{~d}$, and similarly, liberations of ripe eggs will occur on each following day of the reproduction season.

At time of spawning the gonadal index (ovary/body weight) changes from $3.8 \%$ in the morning to $6.7 \%$ just prior to egg liberation in late aftemoon. Contrary to most teleost fish, the gonadal index of males at the 
Fig. 3. Acanthurus nigrofuscus. Ovary lamellae and ripening of ovocytes. (a) Ovary lamellae and vitellogenesis (May) $(\times 100$ ) (b) Ripe ovum with pachyten chromosomes in central nucleus $(\times 400)$. (c) Ovulated egg with peripheral nucleus and swollen yolk vesicles $(x 400)$. (d) Prespawned egg with homogenized yolk and fat vacuole $(\times 400)$. Ch: chorion; $\mathrm{F}$ : follicle; $\mathrm{GC}$ : granulosa cells; $\mathrm{HY}$. homogenized yolk; LC: lampbrush chromosomes; LM: membrane of lamellae; $N$ : nucleus; OD: oil droplet; OP: egg plasma; PrO: previtellary ovocytes
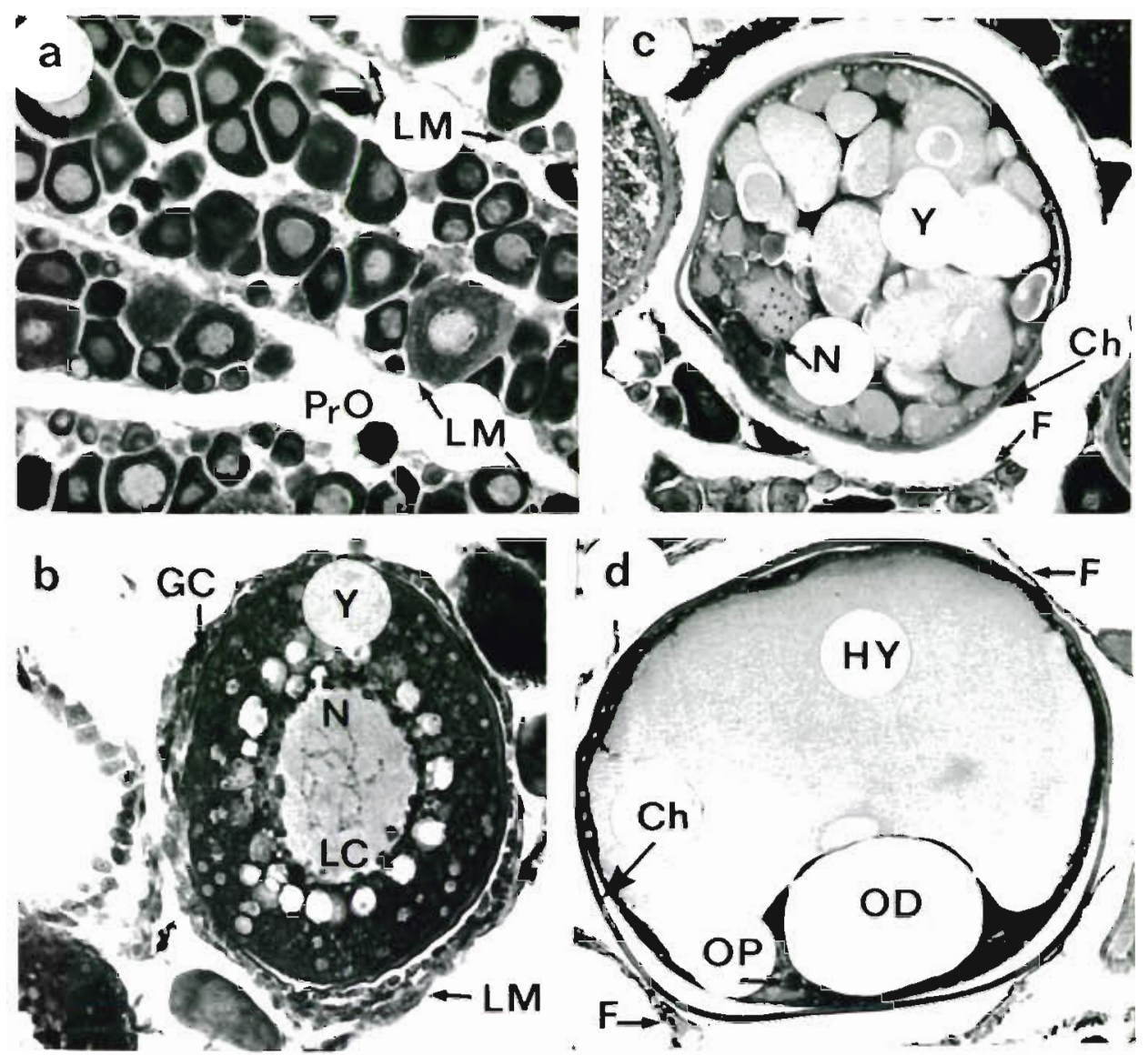

peak of reproduction is higher than the females, being 7.2 to $8.2 \%$. This suggests that the dynamics of energy and nutrient allocation is seasonally different in the sexes.

It is evident from Table 1 that the onset of growth (February) of the male gonad precedes that of the female. Table 1 also includes the growth calculations (condition factor) for comparison with gonadal development. The development of the male gonad commences in April, but immediately exceeds the index of the female gonad. The high indices of both female and male gonads continue until the end of August and then abruptly decline; this heralds the end of reproductive effort. As evident from Table 1, towards the time of reproduction the growth of fish declines and most of the available energy is channelled into the gonads, allowing the continuous proliferation of gametes.

The abrupt decrease of the gonadal index postreproduction is well illustrated from the general appearance of the gonads, as seen during dissections. The annual cycle of the gonadal index, illustrated in Fig. 4, shows the immense differences between the summer and winter situations.

Both the female and male gonads undergo an annual cycle, with minimal growth during the months of November to February, and accelerating growth thereafter. The latter reaches its highest point in July, with

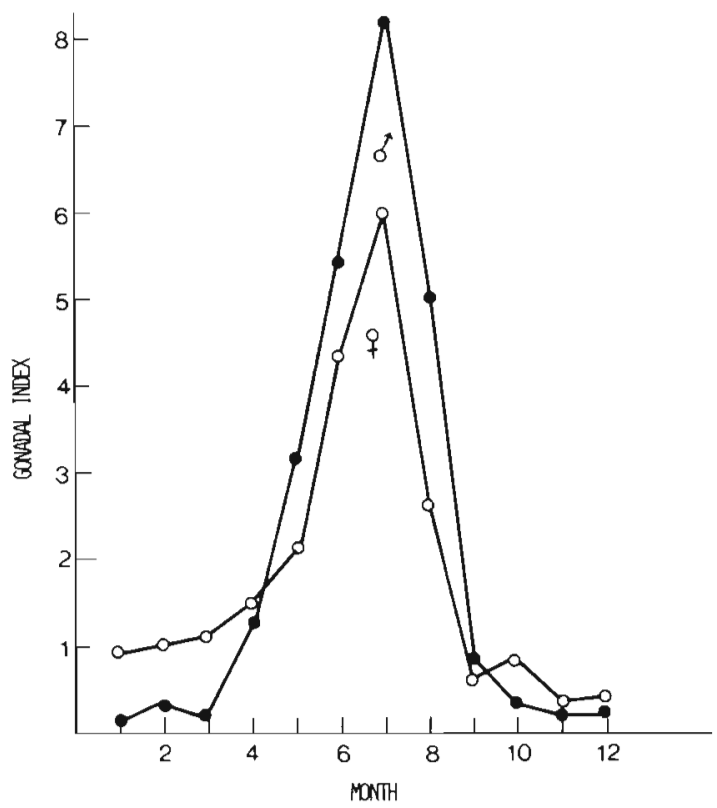

Fig. 4. Acanthurus nigrofuscus. Monthly gonadal index of males and females 
gonad weight being $8 \%$ of body weight in males and $6 \%$ in females. It is also evident from Fig. 4 that ripening of the male gonad is faster than that of the female. This is also apparent from observations on agonistic interactions as well as ritualized swimming displayed by these fish even before actual spawning begins (Myrberg et al. 1985). Unusual for most known gonadal indices of teleosts, the testes are relatively larger than the ovaries (see also Robertson et al. 1979).

These seasonal developments are also seen within the ovigerous lamellae of the ovary. Since the main cells of these lamellae are gametes, their development and growth should be evident from their numbers found in single lamellae. This is illustrated in Fig. 5. Although the lamellae attain their maximal length during the months May to August, they bear the smallest number of ovocytes at this time. This indicates that instead of many small ovocytes characteristic of the winter gonad, the lamellae during the spawning season are occupied by fewer, but larger cells (Fig. 5). This increase in the size of the ovocytes is shown in Fig. 6. Evidently, the largest preovulatory ovocytes, 290 to 335 $\mu \mathrm{m}$ in diameter, are found only during the months of reproduction. From October to March, the germinative layer of the ovary is occupied by small egg cells, many of them luteinized and degenerating

Post-spawning developments in the gonads

Two remarkable phenomena were repeatedly observed during the reproduction season of Acanthurus nigrofuscus. First, in following tagged individuals, it became obvious that many of them return to the spawning site daily during the months of reproduction (Myrberg et al. unpubl.). This means that the polycyclic ovaries produce new batches of eggs on a daily basis. This was also evident from daily catches of groups of females: at dawn all of them had ovulated eggs in their ovary lumens. In the middle of September this process suddenly stopped. Ovaries at that time revealed ripe eggs as well as preovulatory ovocytes. By following the fate of the yolk-laden egg cells, we found that, commencing in October, 2 types of phagocytic processes occurred in the female gonad; one degradive process occurred around the ovulated, non-spawned eggs; phagocytic cells penetrated the chorion and egg membrane, and slowly destroyed the content. The end product of this process was an amorphic postovulatory atretic body (Fig. 7), as described for many teleosts (Bun Ng \& Idler 1983).

An entirely different process occurred around the ripe, preovulated egg cells. Cells forming the surrounding granulosa commenced growth and proliferation (Fig. 8a), finally enclosing the eggs with a columnar

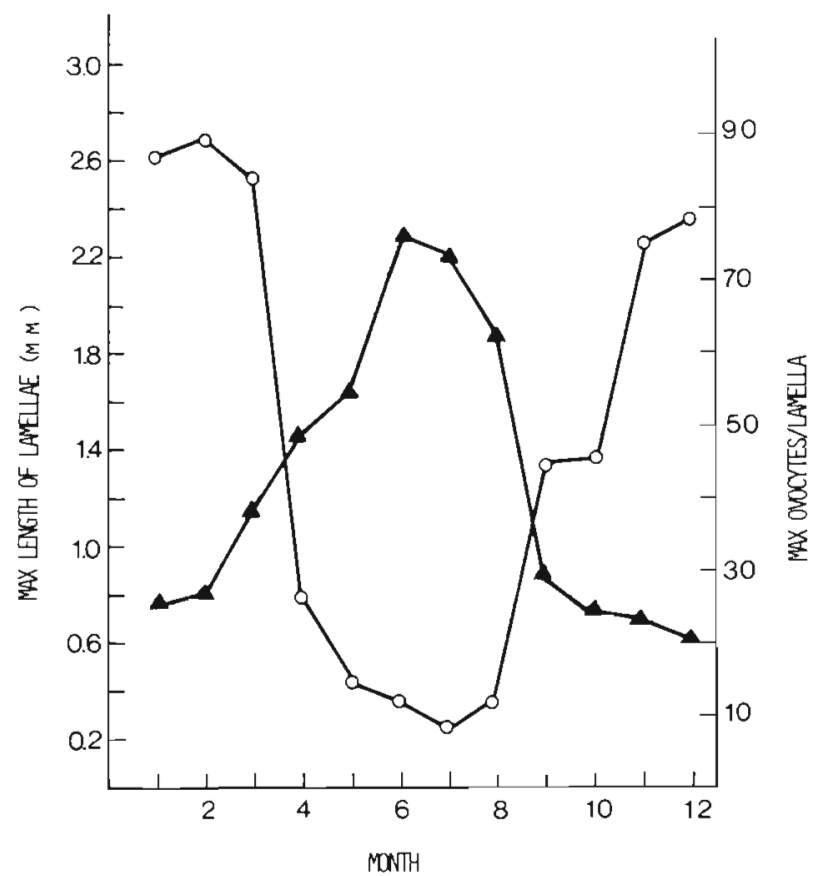

Fig. 5. Acanthurus nigrofuscus. Maximal length of ovigerous lamellae (4) and maximal number of ovocytes (O) in the transects of monthly samples of 5 ovaries ( $n=160$ ovaries)

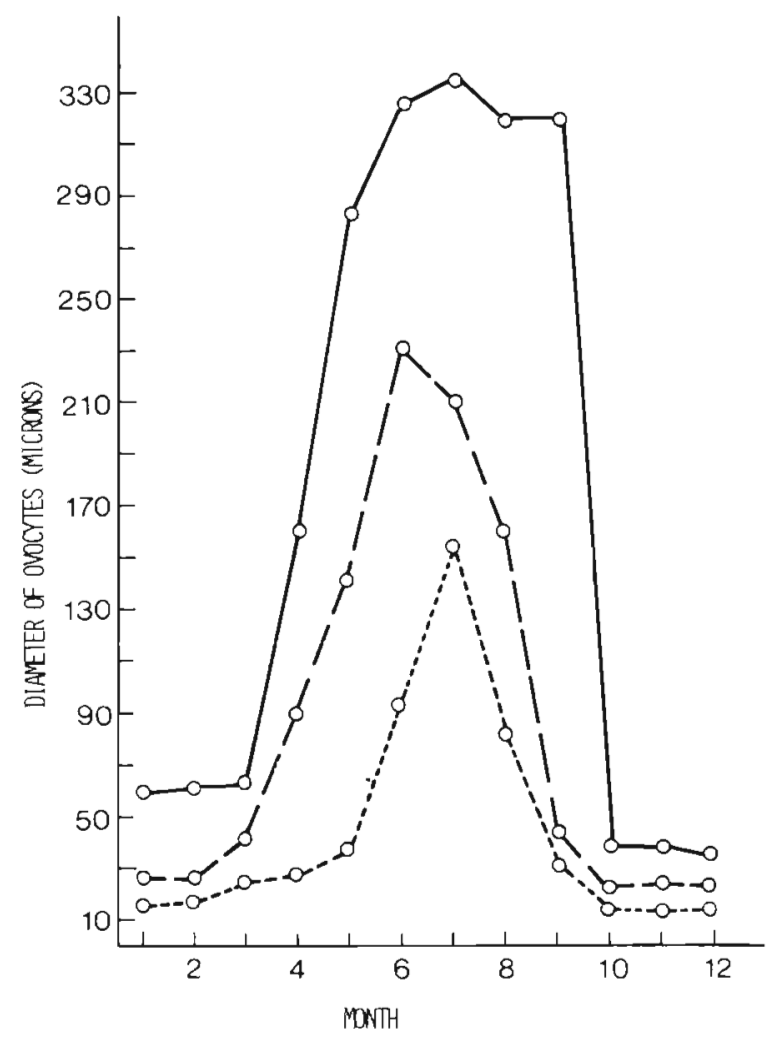

Fig. 6. Acanthurus nigrofuscus. Diameter of ovocytes in various months of the year $(n=160):(-)$ maximal diameter; (---) minimal; (--) average 


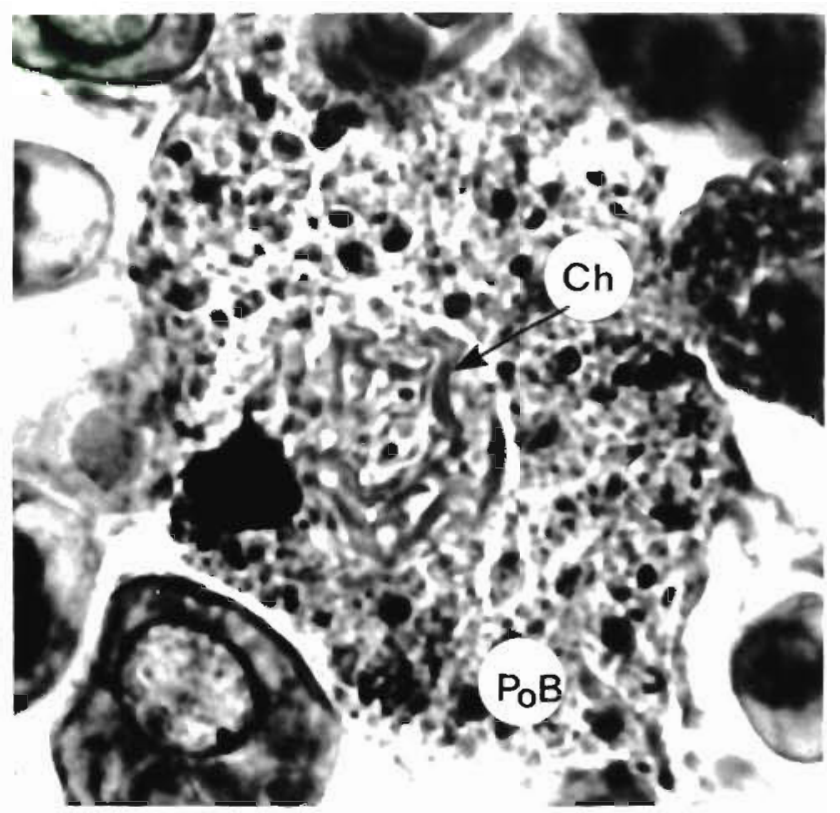

Fig. 7. Acanthurus nigrofuscus. Postovulatory atretic body $(\mathrm{PoB})$ in the ovary. Ch: remnants of chorion $(\times 490)$ epithelium of 2 or more layers. Concomitantly, the egg also began to show structur changes: their cytoplasm and yolk became vacuolized, and the chorion folded (Fig. 8b). The number of this type of atretic bodies increased during November-December; many of them attained diameters of 0.4 to $0.6 \mathrm{~mm}$. A circular, blood capillary network gradually developed around the large preovulatory atretic bodies (Fig. 8c). The end product of this degenerative-formative process was the devouring of the entire egg, and formation of a plac of small cells penetrated by blood capillaries (Fig. 8d). The number of those atretic bodies decreased until about the beginning of March, when renewed recrudescence and ovogenesis commenced. Such organelles were totally absent by the end of March.

An additional, intriguing development was observed at the end of the season in the post-spawning, spent female gonads. Cysts of spermatogonia were detected within the gametogenic layer of the ovigerous lamellae. Initially recorded at the end of September, the cysts include 6 to 10 chromaphilic cells, surrounded by a common membrane (Fig. $9 a$, b). These nests are
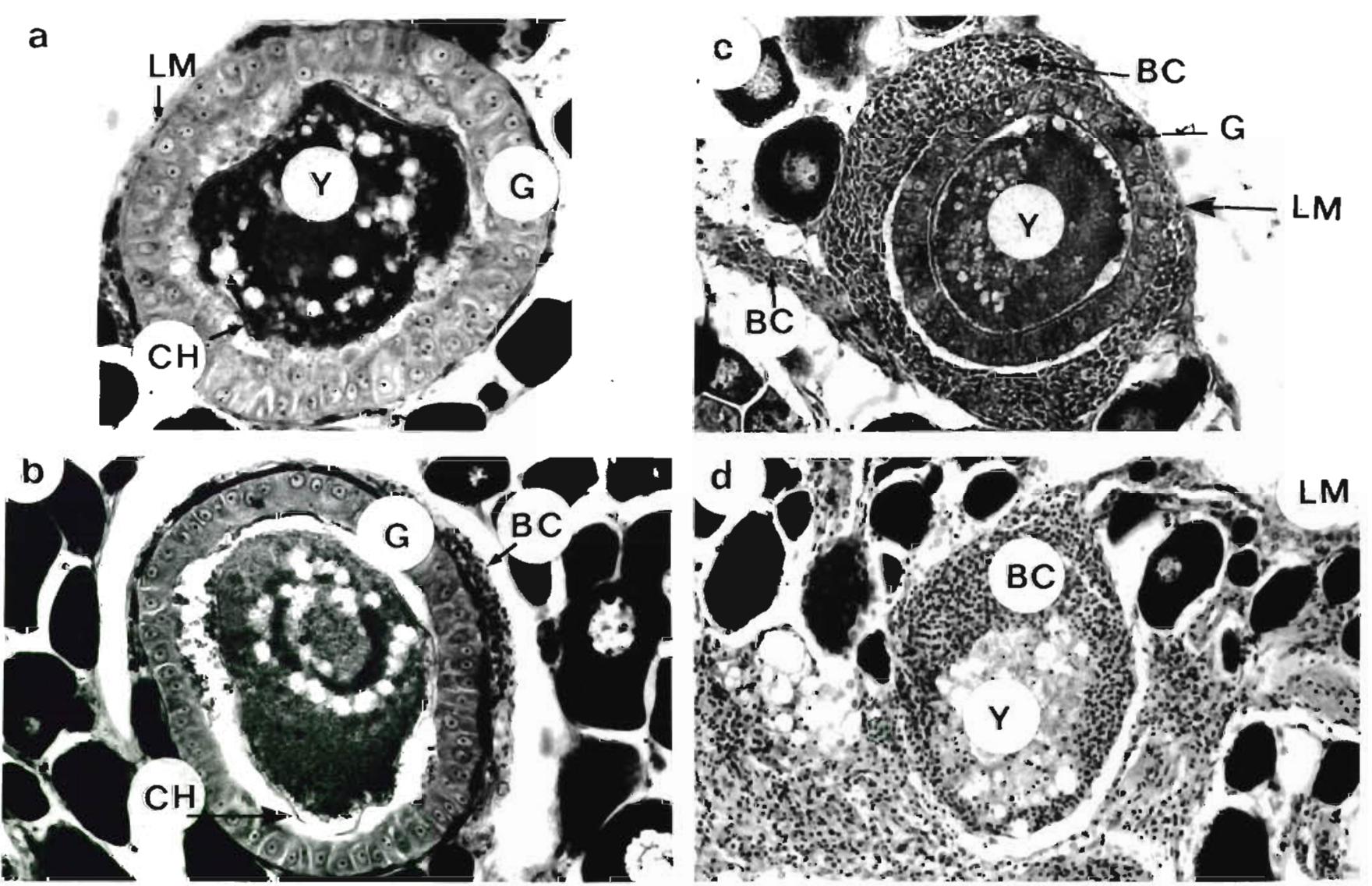

Fig. 8. Acanthurus nigrofuscus. Ripening of a preovulatory atretic body in the ovary. (a) Mitotic divisions and growth of the follicular granulosa $(\times 400)$. (b) Reduction of the egg-structures and origin of surrounding blood capillaries $(\times 400)$. (c) Growth and proliferation of blood net around the atretic body $(\times 400)$. (d) Residuals of blood net and egg at the end of egg absorption $(\times 300)$. $\mathrm{CH}$ : chorion; BC: blood capillarics; G: granulosa; LM: lamellae membrane; Y: yolk 


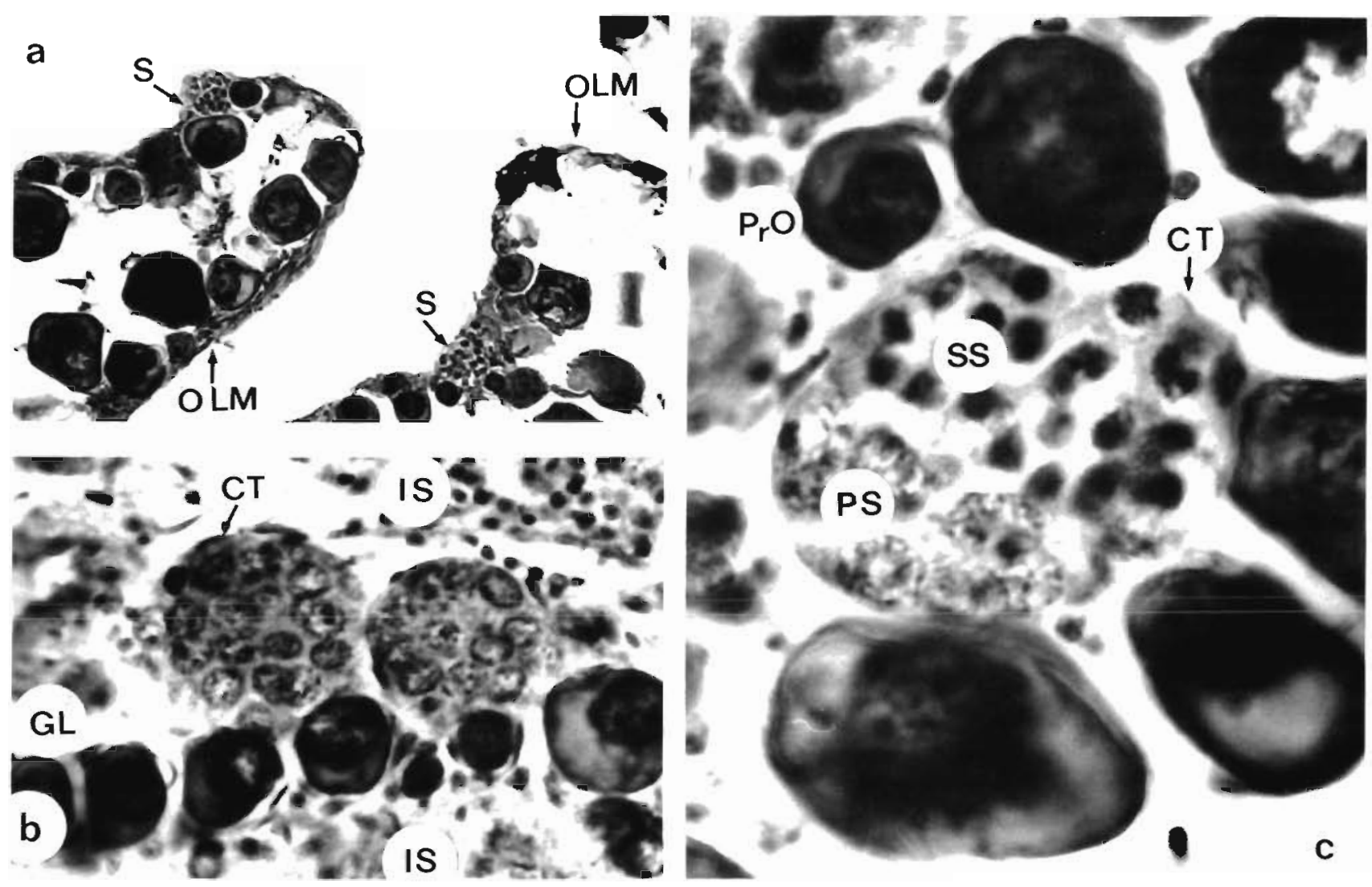

Fig. 9. Acanthurus nigrofuscus. Development of spermatogenic cells in spent ovaries. (a) Nests of spermatogonia in 2 ovary lamellae ( $\times 95)$. (b) Mature testicular cysts $(\times 240)$. (c) Developments of secondary spermatogonia in a female ovary ( $\times 750)$. GL: germinative layer; CT: common tunic of spermatogonial cyst; IS: internal stroma of lamellae; S: nest of male cells; SS: secondary spermatogonia; PS: primary spermatogonia

similar to cysts of spermatogonia observed in gonads of protogynic hermaphroditic fish (Fishelson 1975b, Shpigel \& Fishelson 1983). The number and dimensions of these cysts of male cells increased during December to January and in them mitotic divisions were prominent (Fig. 9c). Accordingly, many pass from the spermatogenic to the spermatid stages. These male cells disappeared abruptly in March, coinciding with the renovation of ovogenesis and vitellogenesis in the ovary. The source of these male cells, as well as their fate, is currently unknown to us.

The male gonads also underwent a pronounced annual cycle of development (Table 1), which can be divided into 2 periods (Table 2 ). One begins at the end of February. This is the time when the spermatogonic tissue begins to reform after the winter dormancy. At this time, testicular tubuli develop, although numerous atretic bodies and remnants of old tubuli still exist. In the search period, in April, the testis is organized and intensive spermatogenesis occurs (Fig. 10a). This intense activity exceeds that shown by the female gonad. The entire core of the testis contains large amounts of ripe and mobile sperm cells by the end of
May. Most sperm cells are now stored in a system of extensive lacunes, supported by muscular stroma (Fig. 10b). In August, there is a reversal of the entire process and hardly any gametogenic cells remain on the supporting tubuli walls. After months of proliferative production of sperm cells, the testis became flaccid, lacunar, with no visible spermatogonic activity. Atretic bodies occupied large parts of testicular stroma (Fig. 10c). This degeneration accelerates in September, as the organ becomes increasingly lacunar, with growing numbers of atretic bodies (Fig. 10d). Such is the structure of the male gonads until reactivation at the end of February.

It should be mentioned that the well-organized preovulatory atretic organs, observed in all female gonads, were never seen in the male gonad. Instead, the atretic bodies within the testes look extremely similar to the postovulatory atretic bodies observed in ovaries.

\section{DISCUSSION}

The behavioral regime of Acanthurus nigrofuscus at Eilat (Gulf of Aqaba) follows a very clear diel pattern of 
Table 2. Acanthurus nigrofuscus. Number and dimensions of atretic bodies in $1241.0 \mathrm{~cm}$ microscope transects of testes in various months $(n=56)$

\begin{tabular}{|lcccl|}
\hline Month & $\begin{array}{c}\text { No. of atretic bodies } \\
\text { per transect }\end{array}$ & \multicolumn{2}{c}{$\begin{array}{c}\text { Diameter } \\
\text { Min. }\end{array}$} & Remarks \\
\hline Jan & $3.4( \pm 0.8)$ & 0.03 & 0.24 & Large lacunae \\
Feb & $2.9( \pm 0.7)$ & 0.10 & 0.30 & Large lacunae \\
Mar & $1.8( \pm 0.2)$ & 0.22 & 0.35 & Renovation of activity \\
Apr & $0.4( \pm 0.2)$ & 0.08 & 0.16 & Testis organized \\
May & $0.02( \pm 0.02)$ & 0.08 & 0.10 & High activity \\
Jun & $0.08( \pm 0.02)$ & - & - & Few atretic bodies \\
Jul & $0.2( \pm 0.1)$ & 0.03 & 0.08 & Testis flaccid \\
Aug & $0.6( \pm 0.05)$ & 0.04 & 0.14 & Lacuna formation \\
Sep & $0.5( \pm 0.2)$ & 0.05 & 0.18 & Extensive atretism \\
Oct & $1.7( \pm 1.3)$ & 0.04 & 0.26 & Growth of lacunae \\
Nov & $2.6( \pm 1.3)$ & 0.05 & 0.25 & Extensive lacunae \\
Dec & & & \\
\hline
\end{tabular}
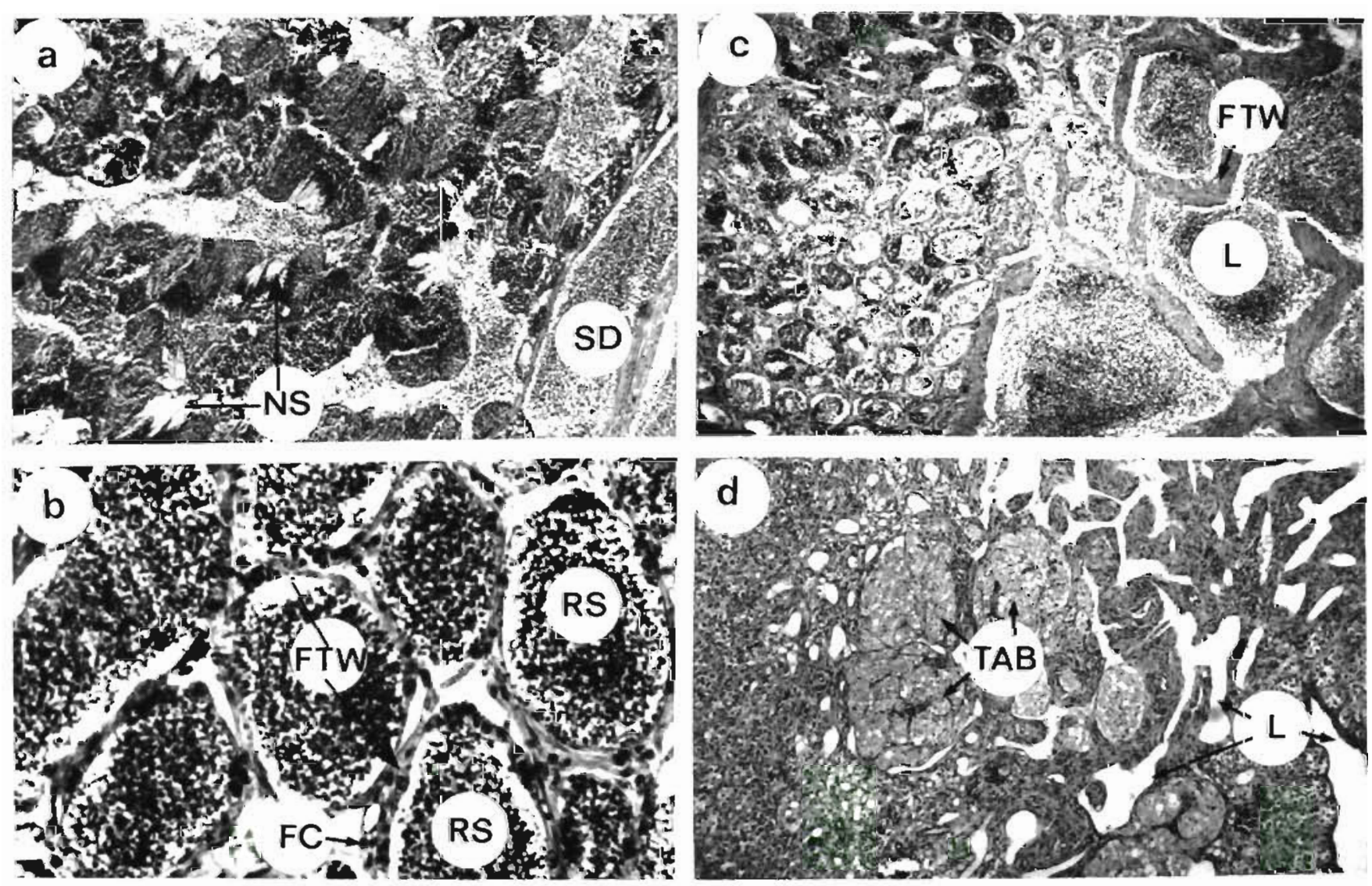

Fig. 10. Acanthurus nigrofuscus. Developments in the testes. (a) Fully developed spermatogenesis with nests of ripe spermatozoids $(\times 100)$. (b) Final stages of sperm production $(\times 250)$. (c) Testicular lacunae and residual sperm (end of Sep; $\times 100)$. (d) Atretic bodies and empty lacunae in a testis $\left(F^{2} b_{i} \times 100\right)$. FC: fibrocytes; FTW: fibrous walls of sperm tubuli; L: lacunae in testes; NS: nests of ripe sperm; SD: sperm duct; RS: residual sperm; TAB: testicular atretic body

migratory movement between the daytime foraging site and the night-refuges. Similar patterns were described for numerous other teleost fish and seem to occur in habitats where the supply of food biomass does not coincide with sufficient availability of protec- tive hides. This is well illustrated in the studied populations of A. nigrofuscus. At the Larome site, where there is plenty of cover but not hiding sites, the home range of the fish extends some 400 to $500 \mathrm{~m}$ (Fig. 1). At the Lighthouse site, where both food and adequate hiding 
sites are found side by side, the fish do not migrate and the home range of a group does not extend alongshore more than 10 to $20 \mathrm{~m}$. This indicates a very important behavioral plasticity, enabling subpopulations of the same species to exploit the habitat in the most economic way.

A changeover in diet for these fish, coupled with seasonal changes in dominant algae and reproduction, was revealed. Although Acanthurus nigrofuscus is a typical herbivore browsing on turf algae (Barlow 1974, Robertson et al. 1979), its diet alternates from the very tiny brown and red algae in summer to the lush and large green algae in winter. This causes a switch from collection of small bits and pieces, involving prolonged activity and energy expenditure, to feeding on large, fleshy algae, which are easily collected and provide far more nutrients per effort expended. This allows the accumulation of high amounts of energy, as for example in the form of special body fats (Fishelson et al. 1985a), and as such, provides an energy base for gonadal development. Therefore, the rich winter diet provides energy for development and gametogenesis, whereas the summer diet provides sufficient energy for subsistence/maintenance and for motoric activity.

The gonadal cycle can be divided into 3 seasons: the first from October to December (winter season), during which the gonads recover from the previous year's activities; the second from January to April (spring season) when reactivation of gametogenesis occurs; the third from May to September (summer season), when synchronized reproduction of the entire adult fish population occurs (Myrberg et al. 1985). During these months the gonadal index shows the highest values.

The gonads are polycyclic, and each female spawns numerous batches of eggs on a daily basis. It is possible that we are dealing with synergic and exogenous rhythms of physiologically controlled events (Nielson 1984). In September, an abrupt arresting of egg liberation occurs, although no drastic changes of ambient conditions in the habitat are observable. This occurs concomitantly with the onset of atresic processes in the gonads, and now the prolonged activity of the ovary enters a refraction stage, marked by the onset of atresion in already-ripe gametes. In the ovary this produces postovulatory atresic bodies, similar to those described in numerous teleost species, and preovulatory atresic organelles that develop around preovulated egg cells. It is possible that those are analogous to the preovulatory 'corpus luteum' described by several authors for teleost fish (Hoar 1957). In Acanthurus nigrofuscus, these atresic organelles begin to appear in September and are found until February. They are characterized by a strong development of the granulosa, which forms pathways for reabsorption of egg-material. Around these granulosa-surrounded ripe eggs, a blood capillary net develops which transports all the absorbed nutrients. The end-product of this regressive process is a dense pack of blood capillaries.

Acording to Liley (1980) and Bun Ng \& Idler (1983), such changes are caused by an abrupt decrease of maturation gonadotropins, induced by exogenous as well as endogenous factors. According to Marshall (1960) and Lam (1983), prolonged high temperatures concomitant with shorter days can induce such a change. These ambient conditions are prevalent in Eilat during the months of reproduction when the temperature is 24 to $26^{\circ} \mathrm{C}$. After July, the days become shorter although the temperatures remain high. If high temperature inhibits vitellogenesis (Lam 1983), then this will prevent ovulation and egg cells will be arrested in development. The same author mentions a refractory period that may occur in gonads preceding prolonged spawning, despite persisting favorable conditions. Such arresting will lead towards absorption of produced eggs. According to Götting (1961), this process also has a blocking effect on the hormonal activity of the ovary. This seems to be the case in Acanthurus nigrofuscus.

At this time cysts of male gametes are detectable within the germinal layer of the ovary lamellae. Their appearance strongly resemble male cysts within ovaries of sex-reversing fish (Gunderman 1972, Fishelson 1975b, Shpigel \& Fishelson 1983). However, in Acanthurus nigrofuscus, which are gonochorists, the male Anlagen do not develop beyond spermatogonia and remain in the ovaries until their ovogenic reactivation in March. This occurrence of male tissue in female gonads seems to coincide with the refraction of female activity (D'Ancona 1950, Chan \& Phillips 1967a, b). Recently, Foster et al. (1983) mentioned that in a variety of teleosts, androgen hormones attain a very high maximum at the end of vitellogenesis. It stands to reason that under such unstable conditions, masculinization of dormant gametic cells can occur within the ovary, which consequently can cause additional hormonal blockage arresting ovogenesis. The same was postulated for the protogynous sex-change in the fish Anthias squamipinnis (Fishelson 1975b). Ovocytosis commences only after a prolonged refraction stage as the female endocrinic activity increases, the ovary overcomes the androgenic blockage, and more testosterone is transformed into estradiole. It may be of interest to reinvestigate already-studied female gonads of various teleosts, that, following intensive spawnings, exhibit prolonged refraction periods and to observe whether there are any cysts of male sex cells present.

Acknowledgements. The authors extend their sincere thanks to A. Diamant, M. Shpigel and A. Kushnir for their assistance in catching the fish, and to A. Tiran for preparation of histo- 
logical sections. Thanks are also due to the $\mathrm{H}$. Steinitz MBL of the Interuniversity Institute in Eilat, where the fieldwork was based. This study was supported by an Israel-U.S. BSF grant$2626 / 81$.

\section{LITERATURE CITED}

Abraham, M., Blanc, N., Yashov, A. (1966). Oogenesis in five species of grey mullets (Teleostei, Mugilidae) from natural and landlocked habitats. Israel J. Zool. 15: 155-172

Barlow, G. W (1974). Contrast in social behavior between Central American cichlid fishes and coral-reef surgeon fish. Am. Zool. 14: 540-546

Bun Ng, T., Idler, D. R. (1983). Yolk formation and differentiation in teleost fishes. In: Hoar, W. S., Randall, D. J., Donaldson, E. (ed.) Fish physiology 9 (A): 373-402

Chan, S. T. H., Philips, J. G. ((1967a). The structure of the gonad during natural sex reversal in Monopterus albus (Pisces, Teleostei). J. Zool., Lond. 151: 169-141

Chan, S. T. H., Philips, J. G. (1967b). Seasonal changes in the distribution of gonadal lipids and spermatogonic tissue in the male phase of Monopterus albus (Pisces, Teleostei). J. Zool., Lond. 152: 31-41

D'Ancona, V. (1950). Determination et differentiation du sex chez les poissons. Archs Anat. microsc. Morph. exp. 39: $274-292$

Fishelson, L. (1975a). Ethology and reproduction of pteroid fishes found in the Gulf of Aqaba (Red Sea), especially Dendrochirus brachypterus (Cuvier) (Pteroidae, Teleostei). Pubbl. Staz. zool. Napoli 39 (Suppl): 635-656

Fishelson, L. (1975b). Ecology and physiolgy of sex reversal in Anthias squamipinnis (Teleostei, Anthiidae). In: O. Reinboth (ed.) Intersexuality in animal kingdom. SpringerVerlag, Heidelberg, p. 284-294

Fishelson, L. (1978). Oogenesis and spawn-formation in the Pigmy lion fish Dendrochirus brachypterus (Pteroidae). Mar. Biol. 46: 341-348

Fishelson, L., Montgomery, L. W., Myrberg, A. A., Jr. (1985a) A new fat body associated with the gonad of surgeonfishes (Acanthuridae, Teleostei). Mar, Biol. 86 (2): 109-112

Fishelson, L., Montgomery, W. L., Myrberg, A. A., Jr (1985b). A unique symbiosis in the gut of tropical herbivorous surgeonfish (Acanthuridae: Teleostei) from the Red Sea. Science 229: 49-51

Foster, A., Jalabert, B., Billard, R., Breton, B., Zohar, Y (1983) The gonadal steroids. In: Hoar, W. S., Randall, D. J., Donaldson, E. M. (ed.) Fish physiology 9 (A): 272-372

Götting, K. J. (1961). Beiträge zur Kenntnis der Grundlagen der Fortpflanzung und zur Fruchtbarkeitsbestimmung bei marinen Teleosteern. Helgoländer wiss. Meeresunters. 8 : $1-41$

Götting, K. J. (1964). Entwicklung Bau und Bedeutung der Eihüllen des Steinpickers (Agonus cataphracutus L.). Helgoländer wiss. Meeresunters. 11. 1-12

Gunderman, N. (1972). Reproductive cycle and sex inversion in Anthias squamipinnis (Peters). M. Sc. thesis, Tel Aviv Univ., Tel Aviv (Hebrew)

Hoar, W. S. (1957). The gonads and reproduction. In: M. E. Brown (ed.) The physiology of fish, Vol. 1. Academic Press, New York, p. 287-321

Jones, R. S. (1968). Ecological relationships in Hawaiian and Johnston Island Acanthuridae (Surgeon fish). Micronesica 4: $309-361$

Lam, T. J. (1983). Environmental influences on gonadal activity in fish. In: Hoar, W. S., Randall, D. J., Donaldson, E. M. (ed.) Fish physiology 9 (A): 65-116

Liley, N. R. (1980). Patterns of hormonal control in the reproductive behavior of fish, and their relevance to fish management and culture programs. In: Bardach, J. E. (ed.) Fish behaviour and its use in the capture and culture of fishes ICLARM Conference Proceedings 5, Manila, p. 210-246

Marshall, A. J. (1960). Reproduction in male bone fish. Symp. zool. Soc. Lond. 1: 137-151

Myrberg, A. A., Jr., Fishelson, L., Montgomery, W. L. (1985). The reproductive behavior of the surgeonfish Acanthurus nigrofuscus on the reefs of Eilat, Israel (Gulf of Aqaba, Red Sea) with emphasis on migration and spawning. 19 Int. Ethological Conference, Toulouse, France, I, p. 255

Nagahama, Y., Kagawa, H. (1982). In vitro steroid production in the postovulatory follicles of the amago salmon (Oncorhynchus rhodurus) in response to salmon gonadotropins. J. exp. Zool. 219: 105-109

Nielson, E. T (1984). Relation of behavioural activity rhythms to the changes of day and night. A revision of views. Behaviour 89: 147-173

Randall, J. (1961a). A contribution to the biology of the convict surgeonfish of the Hawaiian Islands, Acanthurus tristegus sandvicensis. Pacif. Sci. 15: 215-272

Randall, J. (1961b). Observations on the spawning of surgeonfishes (Acanthuridae) in the Society Islands. Copeia 1961: $237-238$

Robertson, D. R. (1983). On the spawning behavior and spawning cycles of eight surgeonfishes (Acanthuridae) from Indo-Pacific. Environ. Biol. Fish. 9: 193-223

Robertson, D. R., Polunin, N. V., Leighton, K. (1979). The behavioral ecology of three Indian Ocean surgeonfishes (Acanthurus lineatus, A. leucostemon, Zebrasoma scopas): their feeding strategies and social and mating systems. Environ. Biol. Fish. 4: 125-170

Shpigel, M., Fishelson, L. (1983). Ecology and sociobiology of coexistence in two species of Dascyllus (Pomacentridae, Teleostei). Bull. Inst. Ocean Fish. (Egypt) 9: 207-224

Stehr, C. M., Hawkes, J. W. (1979). The comparative ultrastructure of the egg membrane and associated pore structures in the starry flounder Platichthys stellatus (Pallas) and pink salmon Oncorhynchus gorbusha (Wal.). Cell Tissue Res. 202: 347-456

Yaron, Z. (1971). Observations on the granulosa cells of Acanthobrama terrasanctae and Tilapia zilii. Gen. Comp. Endocr. 17: 247-252 